\title{
Organic versus conventional fertilization effects on sweet basil (Ocimum basilicum L.) growth in a greenhouse system
}

\author{
Jennifer Bufalo ${ }^{\mathrm{a}, \mathrm{b}, *}$, Charles L. Cantrell ${ }^{\mathrm{b}}$, Tessema Astatkie ${ }^{\mathrm{c}}$, Valtcho D. Zheljazkov ${ }^{\mathrm{d}}$, \\ Archana Gawde ${ }^{b}$, Carmen Sílvia Fernandes Boaro ${ }^{a}$ \\ a Department of Botany, Institute of Biosciences (IB), UNESP - Univ. Estadual Paulista, Botucatu, São Paulo 18618-970, P.O. Box: 510, Brazil \\ ${ }^{\mathrm{b}}$ U.S Department of Agriculture, Agricultural Research Service, Natural Products Utilization Research Unit, University, Mississippi 38677, USA

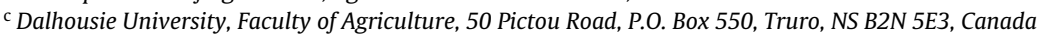 \\ d Columbia Basin Agricultural Research Center, Oregon State University, Pendleton, OR 97801, USA
}

\section{A R T I C L E I N F O}

\section{Article history:}

Received 24 September 2014

Received in revised form 27 March 2015

Accepted 17 April 2015

Available online 26 May 2015

\section{Keywords:}

Nutrients

Nitrogen

Essential oil

(-)-Linalool

Eugenol

\begin{abstract}
A B S T R A C T
Ocimum basilicum L. (sweet basil) is an essential oil producing crop used in culinary and fragrance applications. The objective of this controlled environment study was to evaluate the effects of organic and conventional fertilization (applied at two nitrogen rates, 150 and $250 \mathrm{~kg} \mathrm{~N} / \mathrm{ha}$ ) on plant growth, essential oil yield and chemical profile, and tissue nutrient accumulation in sweet basil. Overall, basil plants fertilized with organic fertilizer at a rate of $150 \mathrm{~kg} \mathrm{~N} /$ ha accumulated greater concentrations of potassium (K) and manganese (Mn). The highest fresh weight was obtained from the plants grown with conventional fertilizer at a rate of $250 \mathrm{~kg} \mathrm{~N} / \mathrm{ha}$. Treatments did not affect the oil content in dried biomass $(0.23-0.36 \%$ range), oil yields (11.4-20.7 mg/pot), nor the concentration of eucalyptol, (-)-linalool, bornyl acetate, eugenol, $\alpha$-trans-bergamotene, germacrene $\mathrm{D}, \mathrm{\gamma}$-cadinene and epi- $\alpha$-cadinol in basil oil. The results from this study demonstrated that organic or conventional fertilizer can alter fresh or dry weight, and nutrient absorption without modifying essential oil composition.
\end{abstract}

(C) 2015 Elsevier B.V. All rights reserved.

\section{Introduction}

Ocimum basilicum L. (sweet basil) is a popular food seasoning belonging to the family Lamiaceae which is characterized by a great variability of morphology and chemotypes (Lawrence, 1988; Marotti et al., 1996). Sweet basil, originally native to India and other regions of Asia, is utilized as an ingredient in Western and Mediterranean diets (Lu et al., 2014). Its leaves contain essential oils of strong aroma. Basil leaves and shoots are used fresh or dried in culinary applications (Grayer et al., 2004; Ozcan et al., 2005). Some studies have reported that sweet basil contains high concentrations of phenolic compounds (rosmarinic and caffeic acid), which are characterized by high antioxidant capacities (Lee and Scagel, 2009; Surveswaran et al., 2007). Basil extracts are also used in the manufacturing of cosmetic and pharmaceutical products or biopes-

\footnotetext{
* Corresponding author at: Department of Botany, Institute of Biosciences (IB), UNESP - Univ. Estadual Paulista, Botucatu, São Paulo 18618-970, P.O. Box: 510, Brazil. Tel.: +55 15 981464967/14 38800124 .

E-mail address: jenniferbufalo@yahoo.com.br (J. Bufalo).
}

ticides (Keita et al., 2001; Pascual-Villalobos and Ballesta-Acosta, 2003; Umerie et al., 1998).

The high economic value of basil oil is due to the presence of a complex mixture of volatile substances, monoterpenes, sesquiterpenes and their oxygenated analogs present at low concentrations in plants (Lucchesi et al., 2004). These oil compounds determine the specific aroma and flavors for each basil species and variety. Basil essential oil is synthesized and stored in glandular trichomes of leaves (Sangwan et al., 2001). Generally the main compounds responsible for the typical aroma are 1,8-cineole, methyl cinnamate, methyl chavicol and linalool (Lee et al., 2005). In basil, more than 200 compounds from the essential oil were identified and different chemotypes have been classified for 0 . basilicum according to the essential oil chemical composition (Grayer et al., 1996; Zheljazkov et al., 2008a). The chemical taxonomical range in basil is highly variable. As reported by Lawrence (1988), four chemotypes of basil are (i) methyl chavicol, (ii) linalool, (iii) methyleugenol, (iv) methyl cinnamate in addition to numerous subtypes. Grayer et al. (1996) reported five chemotypes depending on the relative abundance of the following compounds: linalool; methyl chavicol; both linalool and methyl chavicol; both linalool and eugenol; both methyl chavicol and methyl eugenol. In a study 
with 38 genotypes of sweet basil, Zheljazkov et al. (2008a) identified the following 7 basil chemotypes: (1) high-linalool chemotype [19-73\% (-)-linalool], (2) linalool-eugenol chemotype [six chemotypes with 28-66\% (-)-linalool and 5-29\% eugenol], (3) methyl chavicol chemotype [six accessions with $20-72 \%$ methyl chavicol and no (-)-linalool], (4) methyl chavicol-linalool chemotype [six accessions with 8-29\% methyl chavicol and 8-53\% (-)-linalool], (5) methyl eugenol-linalool chemotype [two accessions with $37 \%$ and $91 \%$ methyl eugenol and $60 \%$ and $15 \%$ (-)-linalool], (6) methyl cinnamate-linalool chemotype [one accession with $9.7 \%$ methyl cinnamate and 31\% (-)-linalool], and (7) bergamotene chemotype [one accession with bergamotene as major constituent, $5 \%$ eucalyptol, and $<1 \%$ (-)-linalool].

Basil oil was reported to have antimicrobial, antioxidant (Hussain et al., 2008; Karagözlü et al., 2011), antifungal (Hossain et al., 2014a) and insecticidal (Popovic et al., 2006; Hossain et al., 2014b) properties and some of its components, such as 1,8-cineole, linalool, and camphor, are known to be biologically active (Morris et al., 1979).

There is a strong interest in growing medicinal and aromatic plants in an effort to produce a desired essential oil chemical profile. Active principle constituents from the basil essential oil are affected by diversified factors: water stress (Ekren et al., 2012; Khalid, 2006), salt stress (Barbieri et al., 2012), extraction processes (Yang et al., 2007) and drying methods (Pirbalouti et al., 2013) as well as, cultivation practices as effect of plant nutrition on sweet basil productivity and essential oil composition (Arabaci and Bayram, 2004; Bowes and Zheljazkov, 2004; Golez et al., 2006; Sinfola and Barbieri, 2006; Zheljazkov et al., 2008a).

The hypothesis of this study was that organic and conventional fertilizer administered to sweet basil would not result in significant differences in growth, essential oil yield or composition. The objective of this study was to evaluate the effects of organic and conventional fertilizers applied at two nitrogen application rates on growth indicators and essential oil production as well as chemical profile in sweet basil cultivated in a greenhouse system.

\section{Material and methods}

\subsection{Location and plant material}

The study was conducted in the greenhouse of the United States Department of Agriculture, Agricultural Research Service (USDAARS), Natural Products Utilization Research Unit in University, Mississippi. Certified organic seeds of sweet basil (O. basilicum L.) 'Genovese' were obtained commercially from Burpee ${ }^{\circledR}$ (W. Atlee Burpee \& Co, Warminster, PA). Seeds were placed in a growth chamber at $25^{\circ} \mathrm{C}$ and $0012 \mu \mathrm{mol}$ light for 40 days with organic choice potting mix (0.10-0.05-0.05) formulated with 55-65\% composted bark, sphagnum peat moss pasteurized poultry litter (Miracle Gro ${ }^{\circledR}$ Marysville, $\mathrm{OH}$ ). After 40 days, basil seedlings (app.15 cm height) were transplanted to $2.0 \mathrm{~L}$ pots filled with organic choice potting mix (Miracle-Gro ${ }^{\circledR}$, Marysville, $\mathrm{OH}$ ) and fertilized with conventional NPK fertilizer (10-10-10) (Shake'n Feed Continuous Release Miracle Gro ${ }^{\circledR}$ Marysville, OH) or organic NPK fertilizer (4-3-4) (Organic Fertilizer, Mighty Grow ${ }^{\circledR}$ Fruitdale, AL). Both the conventional and the organic fertilizers were applied to provide two rates of $\mathrm{N}$; calculated equivalent of 150 and $250 \mathrm{~kg} \mathrm{~N} / \mathrm{ha}$, calculated by the surface area of each pot. Pots were maintained in a greenhouse, with $26^{\circ} \mathrm{C}$ day and $25^{\circ} \mathrm{C}$ night and watering 8:00 am and 4:00 pm each day for 3 min each time. Plants were harvested on both 02 June (68 days after transplanting) and 03 June (69 days after transplanting) both at full bloom, when the essential oil would be optimal (Topalov, 1962). Basil plants were harvested by cutting at $10 \mathrm{~cm}$ above soil surface, the shoot fresh weight was taken. Basil shoots were air-dried until constant weight for 3 days and the dried weight was taken.

\subsection{Plant tissue analyses}

Dry shoot samples were sent to Mississippi State University, Soil Testing and Plant Analysis Laboratory (Starkville, Mississippi) to perform a nutrient analysis to determine the plant tissue levels of

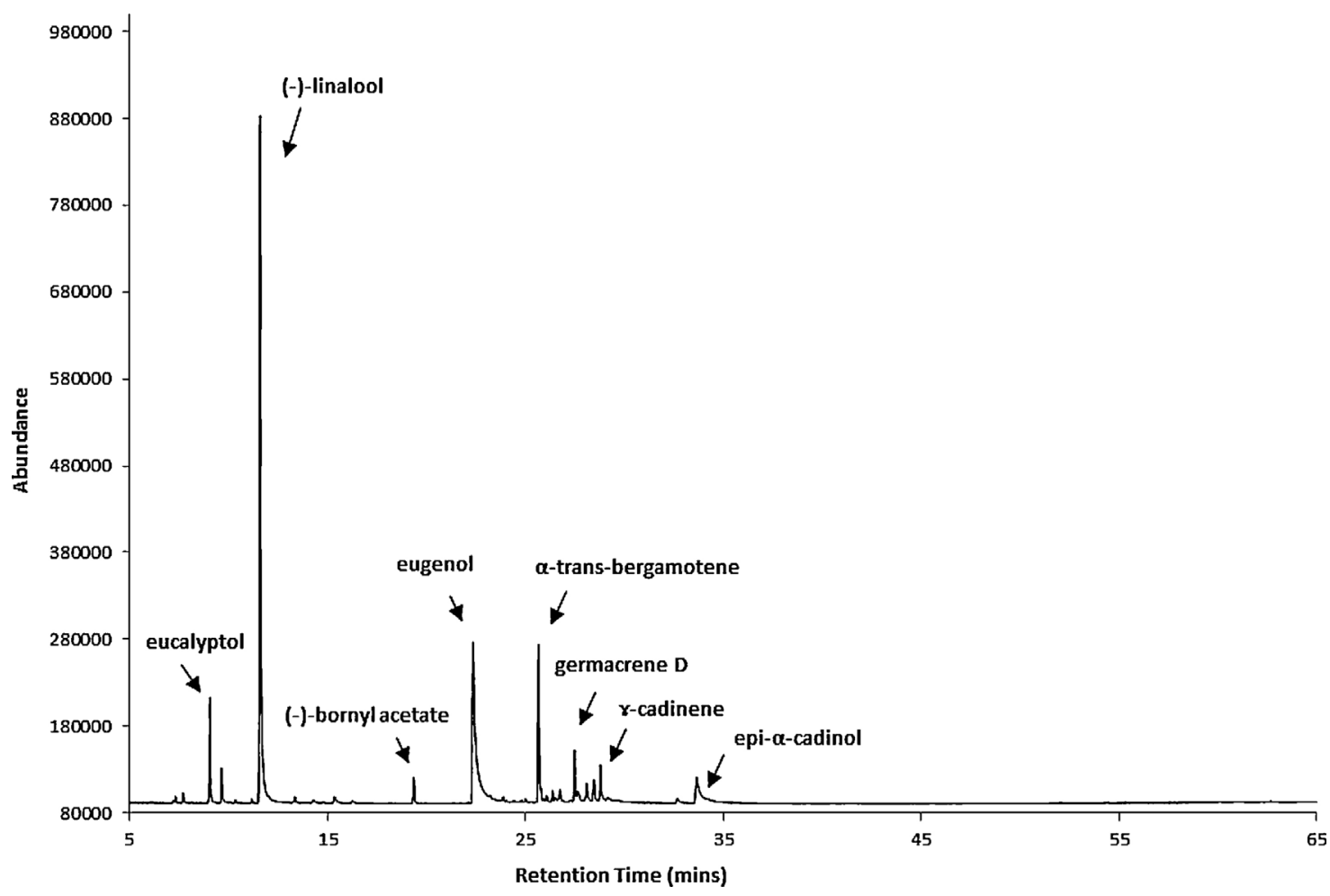

Fig. 1. Representative sweet basil chromatogram (GC-FID). 
N (Nelson and Soommers, 1972), P, K, Ca, Mg, Fe, Zn, B, Mn and Cu (Jones and Steyn, 1973; Isaac and Johnson, 1975).

\subsection{Essential oil isolation}

Fresh aerial parts (ranging from 69 to $180 \mathrm{~g}$ per pot) were subjected to $120 \mathrm{~min}$ steam distillation immediately after harvest. Steam distillation was performed using a Clevenger-type apparatus containing $n$-pentane. Plant material was cut in small pieces and placed into a $2 \mathrm{~L}$ round bottom bioflask. The organic phase ( $n$ pentane) was recovered and concentrated to $1.0 \mathrm{~mL}$ under a stream of dry nitrogen (Potter, 1996). The essential oil content was calculated by weight as $(\mathrm{g})$ of oil per $(\mathrm{g})$ of fresh herbage (stems, leaves, and flowers). However, the results are expressed as (\%) of oil in the dried biomass (corrected for moisture content using the difference between the fresh and dried weight of the biomass samples). The oil yield was expressed in ( $\mathrm{mg}$ ) per pot.

\subsection{Gas chromatography}

Using a micropipet, $10 \mu \mathrm{L}$ of oil from each sample was transferred into a $10 \mathrm{~mL}$ volumetric flask. Samples were brought to volume with $\mathrm{CHCl}_{3}$. A $1 \mathrm{~mL}$ aliquot of each oil sample was placed by glass pipet into a GC vial for analysis.

\subsubsection{GC analysis}

A total of eight constituents were identified and quantified in basil essential oil (Fig. 1). Chemical standards and compounds were analyzed on an Agilent 7890 A GC System using GC was equipped with a DB-5 column $(30 \mathrm{~m} \times 0.25 \mathrm{~mm}$ fused silica cap. column, film thickness of $0.25 \mu \mathrm{m}$ ) operated using the following conditions: injector temp., $240^{\circ} \mathrm{C}$; column temp., $60-240^{\circ} \mathrm{C}$ at $3^{\circ} \mathrm{C} / \mathrm{min}$, held at $240^{\circ} \mathrm{C}$ for $5 \mathrm{~min}$; carrier gas, He; injection volume, $5 \mu \mathrm{l}$ (split on FID, split ratio 25:1); MS mass range from 40 to $650 \mathrm{~m} / \mathrm{z}$; filament delay of $3 \mathrm{~min}$; target total ion chromatogram (TIC) of 20,000 ; a prescan ionization time of $100 \mu \mathrm{s}$; an ion trap temperature of $150^{\circ} \mathrm{C}$; manifold temperature of $60^{\circ} \mathrm{C}$; and a transfer line temperature of $170^{\circ} \mathrm{C}$; simultaneous detection with MS and FID by splitting the column outlet $(1: 1)$. Detector temperature for FID is $300^{\circ} \mathrm{C}$.

\subsubsection{GC/MS analysis}

Commercial standards eugenol, obtained from Aldrich (St. Louis, MO), and eucalyptol, (-)-linalool, and (-)-bornyl acetate, all from Fluka (Buchs, Switzerlands), were injected and compared with retention time and mass spectra data of basil essential oil. Compounds $\alpha$-trans-bergamotene, germacrene $\mathrm{D}, \mathrm{\gamma}$-cadinene and epi- $\alpha$-cadinol were identified by Kovat analysis (Adams, 2009), and comparison of mass spectra with those reported in the NIST mass spectra database. Kovats indices were calculated using equation $\mathrm{KI}$ $(x)=100\left[\left(\log \mathrm{RT}(x)-\log \mathrm{P}_{z}\right) /\left(\log \mathrm{RT}\left(\mathrm{P}_{z+1}\right)-\log \mathrm{RT}\left(\mathrm{P}_{z}\right)\right]\right.$ where: RT $\left(\mathrm{P}_{z}\right) \leq \mathrm{RT}(x) \leq \mathrm{RT}\left(\mathrm{P}_{z+1}\right)$ and $\mathrm{P}_{4} \ldots \mathrm{P}_{25}$ are $n$-paraffins.

\subsubsection{GC/FID analysis}

Compounds were quantified by performing area percentage calculations based on the total combined FID area. For example, the area for each reported peak was divided by total integrated area from the FID chromatogram from all reported peaks and multiplied by 100 to arrive at a percentage. The percentage is a peak area percentage relative to all other constituents integrated in the FID chromatogram.

\subsection{Statistical analysis}

The effect of fertilizer (2 levels: conventional and organic) and nitrogen rate (2 levels: 150 and $250 \mathrm{~kg} / \mathrm{ha}$ ) on basil growth indicators (fresh weight ( $\mathrm{g}$ ), dry weight (mg), and moisture content (\%)), essential oil (percent area (\%) of eucalyptol, (-)-linalool, (-)-bornyl acetate, eugenol, $\alpha$-trans-bergamotene, germacrene $\mathrm{D}$, $\mathrm{r}$-cadinene, epi- $\alpha$-cadinol, as well as oil yield (mg/pot), and oil content (\%)), and tissue analysis $(\mathrm{N}(\mathrm{g} / \mathrm{kg}), \mathrm{P}(\mathrm{g} / \mathrm{kg}), \mathrm{K}(\mathrm{g} / \mathrm{kg}), \mathrm{Ca}(\mathrm{g} / \mathrm{kg}), \mathrm{Mg}(\mathrm{g} / \mathrm{kg})$, Fe (mg/kg), Mn (mg/kg), Zn ( $\mathrm{mg} / \mathrm{kg}), \mathrm{Cu}(\mathrm{mg} / \mathrm{kg})$, and B ( $\mathrm{mg} / \mathrm{kg})$ ) was determined using a $2 \times 2$ factorial in 3 blocks design. The two factors of interest (fertilizer, and nitrogen rate) were considered as fixed, and block was considered as random. The analyses were completed using the Mixed Procedure of SAS (SAS Institute Inc., 2010), and further multiple means comparison was completed for significant ( $p$-value $<0.05)$ and marginally significant $(0.05<p$-value $<0.1)$ effects by comparing the least squares means of the corresponding treatment combinations. Letter groupings were generated using a $5 \%$ level of significance. For each response, the validity of model assumptions was verified by examining the residuals as described in Montgomery (2013) and appropriate transformations were applied on responses with violated assumptions. The results reported in the tables and figures are back transformed to the original scale.

\section{Results and discussion}

\subsection{Basil growth indicators}

Growth parameters were taken to determine if organic and conventional fertilization and nitrogen rates influence plant development and composition. The results obtained showed that there was an influence by source fertilizer used and $\mathrm{N}$ rate. Plant tissue $\mathrm{N}$ concentration ranged from 16.4 to $27.5 \mathrm{~g} / \mathrm{kg}$ (Table 1). Plants under organic fertilizer at $150 \mathrm{~kg} \mathrm{~N} / \mathrm{ha}$ accumulated higher concentrations of nitrogen $(\mathrm{N})$, potassium $(\mathrm{K})$ and phosphorus $(\mathrm{P})$. Overall, tissue $\mathrm{Ca}$ and $\mathrm{Mg}$ were also higher in plants grown at both rates of organic fertilizer (Table 1).

Tissue $\mathrm{Mn}$ and $\mathrm{Zn}$ were higher in plants grown with organic fertilizer than at the $150 \mathrm{~kg} \mathrm{~N} /$ ha conventional fertilizer treatment (Table 1). Tissue Fe was the highest in plants at the $150 \mathrm{~kg} \mathrm{~N} / \mathrm{ha}$ organic fertilizer treatment and lower in the plants from all other

Table 1

Macronutrient and micronutrient tissue analysis $(\mathrm{g} / \mathrm{kg})$ of Ocimum basilicum plants cultivated under organic and mineral fertilization and nitrogen rate.

\begin{tabular}{|c|c|c|c|c|c|c|c|c|c|c|c|}
\hline Fertilizer & Nitrogen (kg/ha) & $\mathrm{N}(\mathrm{g} / \mathrm{kg})$ & $\mathrm{K}(\mathrm{g} / \mathrm{kg})$ & $\mathrm{Ca}(\mathrm{g} / \mathrm{kg})$ & $\mathrm{P}(\mathrm{g} / \mathrm{kg})$ & $\mathrm{Mg}(\mathrm{g} / \mathrm{kg})$ & $\mathrm{Fe}(\mathrm{mg} / \mathrm{kg})$ & $\mathrm{Mn}(\mathrm{mg} / \mathrm{kg})$ & $\mathrm{Zi}(\mathrm{mg} / \mathrm{kg})$ & $\mathrm{Cu}(\mathrm{mg} / \mathrm{kg})$ & $\mathrm{B}(\mathrm{mg} / \mathrm{kg})$ \\
\hline \multicolumn{2}{|c|}{ Conventional150 } & $17.00 \mathrm{~b}$ & $17.03 \mathrm{~b}$ & $8.03 \mathrm{~b}$ & $3.17 \mathrm{~b}$ & $2.73 \mathrm{c}$ & $25.70 \mathrm{~b}$ & $237 \mathrm{~b}$ & $36.00 \mathrm{c}$ & $67.67 \mathrm{a}$ & $11.67 \mathrm{ab}$ \\
\hline & 250 & 17.77 b & $13.60 \mathrm{~b}$ & $10.00 \mathrm{~b}$ & $3.63 \mathrm{~b}$ & $3.60 \mathrm{bc}$ & $27.33 \mathrm{~b}$ & $390 \mathrm{ab}$ & $69.33 \mathrm{bc}$ & $135 \mathrm{a}$ & $10.67 \mathrm{~b}$ \\
\hline \multirow[t]{2}{*}{ Organic } & 150 & $27.50 \mathrm{a}$ & $42.07 \mathrm{a}$ & $27.80 \mathrm{a}$ & $5.50 \mathrm{a}$ & $6.20 \mathrm{ab}$ & $50.00 \mathrm{a}$ & $673 a$ & $140 \mathrm{ab}$ & $129 \mathrm{a}$ & $18.00 \mathrm{ab}$ \\
\hline & 250 & $16.43 \mathrm{~b}$ & $24.97 \mathrm{~b}$ & $31.90 \mathrm{a}$ & $4.07 \mathrm{ab}$ & $6.37 \mathrm{a}$ & $29.00 \mathrm{~b}$ & $609 a$ & $168 \mathrm{a}$ & $132 \mathrm{a}$ & $18.67 a$ \\
\hline \multicolumn{12}{|l|}{$p$-value ${ }^{*}$} \\
\hline \multicolumn{2}{|l|}{$\mathrm{F}$} & 0.020 & 0.086 & 0.808 & 0.049 & 0.663 & 0.009 & 0.290 & 0.921 & 0.178 & 0.721 \\
\hline \multicolumn{2}{|l|}{$\mathrm{N}$} & 0.034 & 0.022 & 0.498 & 0.387 & 0.524 & 0.019 & 0.650 & 0.217 & 0.156 & 0.943 \\
\hline \multicolumn{2}{|l|}{$\mathrm{F} \times \mathrm{N}$} & 0.052 & 0.002 & 0.003 & 0.015 & 0.006 & 0.005 & 0.013 & 0.004 & 0.220 & 0.018 \\
\hline
\end{tabular}

* ANOVA $p$-values for the main and interaction effects of Fertilizer (F), and Nitrogen rate (N). Significant effects that need multiple means comparison are shown in bold. Means followed by the same letter are not significantly different. 
Table 2

Growth indicators of Ocimum basilicum plants cultivated under organic and mineral fertilization nitrogen rate.

\begin{tabular}{llll}
\hline Fertilizer & Nitrogen $(\mathrm{kg} / \mathrm{ha})$ & Fresh weight $(\mathrm{g})$ & Dry weight $(\mathrm{g})$ \\
\hline Conventional & 150 & $29.42 \mathrm{~b}$ & $4.37 \mathrm{~b}$ \\
& 250 & $55.02 \mathrm{a}$ & $8.99 \mathrm{a}$ \\
Organic & 150 & $46.02 \mathrm{a}$ & $4.77 \mathrm{~b}$ \\
& 250 & $33.97 \mathrm{~b}$ & $3.89 \mathrm{~b}$ \\
p-value & & & \\
F & & 0.489 & 0.001 \\
N & & 0.041 & 0.023 \\
F $\times$ N & $\mathbf{0 . 0 0 1}$ & $\mathbf{0 . 0 0 1}$ \\
\hline
\end{tabular}

ANOVA $p$-values for the main and interaction effects of Fertilizer (F), and Nitrogen rate $(\mathrm{N})$. Significant effects that need multiple means comparison are shown in bold. Means followed by the same letter are not significantly different.

treatments. Tissue B was the highest in plants in the $250 \mathrm{~kg} \mathrm{~N} / \mathrm{ha}$ organic fertilizer treatment and lower in the plants from the same conventional treatment, while tissue $\mathrm{Cu}$ was not affected by the treatments (Table 1 ).

These results are in agreement with previous reports. For example, Rasouli-Sadaghian et al. (2010) reported that in sweet basil (O. basilicum) fertilized with conventional fertilizers the concentrations were in the following order $\mathrm{K}, \mathrm{Ca}, \mathrm{N}, \mathrm{Mg}$ and $\mathrm{P}, 14.7,10.5$, 9.4, 3.5 and $0.5 \mathrm{mg} /$ pot, respectively, and micronutrients were $\mathrm{Fe}$, $640.1 \mu \mathrm{g} /$ pot, Cu $67.5 \mu \mathrm{g} /$ pot, and Mn $304.9 \mu \mathrm{g} /$ pot. Singh et al. (2014), in trials with sweet basil (O. basilicum) cultivated with combined applications of manure and inorganic fertilizer in different proportions showed the highest content of $\mathrm{N}, \mathrm{P}$ and $\mathrm{K}$ when plants were fertilized with $50 \%$ each of inorganic fertilizer and manures with $3.37 \% \mathrm{~N}, 3.14 \% \mathrm{~K}$ and $0.70 \% \mathrm{P}$. Based on plants grown with manure, the content results were N $2.37 \%, \mathrm{~K} 1.63 \%$ and $\mathrm{P} 0.58 \%$ better than plants grown with only inorganic fertilizer N 2.28\%, K $1.92 \%$ and $\mathrm{P} 0.42 \%$.

Fresh weight yields were higher in the $150 \mathrm{~kg} \mathrm{~N} / \mathrm{ha}$ organic and in the $250 \mathrm{~kg} \mathrm{~N} /$ ha conventional fertilizer treatments and lower in the other treatments, however, dry biomass yields were higher in the $250 \mathrm{~kg} \mathrm{~N} / \mathrm{ha}$ conventional fertilizer treatment and lower in the other treatments (Table 2). Oil content in dried biomass (0.23-0.36\% range), oil yields $(11.4-20.7 \mathrm{mg} /$ pot) and moisture content of the biomass (83.7-89.5\%) were not affected by the treatments (data not shown). Previous studies with sweet basil found similar essential oil content: 0.39-0.97\% (Zheljazkov et al., 2008a); 0.07-1.37\% (Anwar et al., 2005); and 0.04-0.70\% (Simon et al., 1999). Several studies (Biasi et al., 2009; Silva et al., 2006; Teles et al., 2014) reported the effect of fertilization on essential oil production of medicinal plants shown that such practice does not increase essential oil production, as observed in our study.
Our results are in general agreement with literature reports. According to Carrubba (2009), the response of crops to $\mathrm{N}$ fertilization varies according to many factors, as well as environmental conditions, genotype, type of fertilizer and timing of its application. Seufert et al. (2012) reported that when organic systems receive higher quantities of $\mathrm{N}$ than conventional systems, organic performance improves, whereas conventional systems do not benefit from more N. Some authors reported that the agronomic efficiency or $\mathrm{N}$ uptake in plants decreased with increasing levels of conventional $\mathrm{N}$ fertilization. Zheljazkov et al. (2008a) did not observe increases at fresh herbage yield with increasing $\mathrm{N}$ rates in sweet basil plants grown with conventional fertilizer, although when rates of 60,120 and $180 \mathrm{~kg} /$ ha of $\mathrm{N}$ were applied, better yields were observed in plants with $60 \mathrm{~kg} / \mathrm{ha} \mathrm{N}$. Sinfola and Barbieri (2006) reported an increase for dry-to-fresh weight ratio in basil plants fertilized with $100 \mathrm{~kg} \mathrm{ha}^{-1} \mathrm{~N}$ and also with control treatment $\left(0 \mathrm{~N} \mathrm{~kg} \mathrm{ha}^{-1}\right)$ and less weight was observed at plant with $300 \mathrm{~N} \mathrm{~kg} \mathrm{ha}^{-1}$. Berry et al. (2002) reported N availability as responsible for lower yields in many organic systems, because the release of plant available mineral $\mathrm{N}$ from organic sources such as animal manure is slow and this may not provide $\mathrm{N}$ at an adequate rate during growing period. Singh et al. (2014) found better results for fresh herb yield in sweet basil when plants were fertilized with $50 \%$ each of inorganic and organic manures showing a mean of $20.89 \mathrm{mg} / \mathrm{ha}$, better than only inorganic fertilizer $(16.36 \mathrm{mg} / \mathrm{ha}$ with $100 \mathrm{~kg} / \mathrm{ha} \mathrm{N}$ rate) or just organic manure $(18.85 \mathrm{mg} / \mathrm{ha})$. These authors reported that integration of organic manure with inorganic fertilizer may increase the water holding capacity of soil which helps in dissolution of nutrients resulting in a higher nutrient uptake and better yields.

\subsection{Essential oil composition and production of $\mathrm{O}$. basilicum}

Eight compounds were identified in the basil oil from this study (Fig. 1) and quantified according to their percent area. Fertilizer and nitrogen rate did not have significant effect on essential oil composition except on (-)-bornyl acetate (1.6-3.3\% of the total oil; Table 3) where the interaction effect of these factors was marginally significant $(p$-value $=0.08) .(-)$-Linalool $(37.9-46.6 \%)$ was the main compound found in the essential oils followed by eugenol (19.6-21.3\%), $\alpha$-trans-bergamotene (11.4-13.3\%), epi- $\alpha$ cadinol (3.3-6.2\%), germacrene D (4.0-5.6\%), eucalyptol (1.9-5.3\%) and $\mathrm{r}$-cadinene (3.0-4.3\%) (Table 3 ). Such a profile is similar to the reports of other authors who evaluated the chemical composition of essential oil from $O$. basilicum plants (Zheljazkov et al., 2008a,b). Examining the oil profile found in our results, sweet basil (O. basilicum) cultivar 'Genovese' would be classified as a linalool and eugenol chemotype (Grayer et al., 1996), due to the relative

Table 3

Essential oil composition of Ocimum basilicum plants cultivated under organic and mineral fertilization nitrogen rate identified by retention time and Kovats Index.

\begin{tabular}{|c|c|c|c|c|c|c|c|c|c|}
\hline & \multirow[t]{2}{*}{ Oil composition (\%) } & \multirow[t]{2}{*}{$\mathrm{RT}^{\mathrm{a}}$} & \multirow[t]{2}{*}{ KIc. $^{a}$} & \multirow[t]{2}{*}{ KIlit. $^{a}$} & \multicolumn{2}{|c|}{ Conventional } & \multicolumn{2}{|l|}{ Organic } & \multirow[t]{2}{*}{$p$-value $\mathrm{F} \times \mathrm{N}$} \\
\hline & & & & & $\begin{array}{l}\mathrm{N}(\mathrm{kg} / \mathrm{ha}) \\
150\end{array}$ & 250 & 150 & 250 & \\
\hline 1 & Eucalyptol & 9.091 & 1036 & 1031 & $2.98 \mathrm{a}$ & $5.27 \mathrm{a}$ & $2.90 \mathrm{a}$ & $1.86 \mathrm{a}$ & 0.127 \\
\hline 2 & (-)-Linalool & 11.629 & 1109 & 1096 & $37.91 \mathrm{a}$ & $46.64 \mathrm{a}$ & $40.18 \mathrm{a}$ & $40.79 a$ & 0.260 \\
\hline 3 & (-)-Bornyl acetate & 19.385 & 1294 & 1285 & $3.28 \mathrm{a}$ & $2.90 \mathrm{a}$ & $1.55 \mathrm{~b}$ & $2.67 \mathrm{a}$ & 0.080 \\
\hline 4 & Eugenol & 22.372 & 1361 & 1359 & $21.25 \mathrm{a}$ & $19.58 \mathrm{a}$ & $19.61 \mathrm{a}$ & $20.53 \mathrm{a}$ & 0.590 \\
\hline 5 & $\alpha$-Trans-bergamotene & 25.703 & 1439 & 1434 & $12.98 \mathrm{a}$ & $11.42 \mathrm{a}$ & $13.30 \mathrm{a}$ & $13.77 \mathrm{a}$ & 0.537 \\
\hline 6 & Germacrene D & 27.527 & 1488 & 1481 & $5.55 \mathrm{a}$ & $3.96 \mathrm{a}$ & $5.58 \mathrm{a}$ & $5.12 \mathrm{a}$ & 0.607 \\
\hline 7 & в-Cadinene & 28.830 & 1521 & 1513 & $4.16 \mathrm{a}$ & $2.98 \mathrm{a}$ & $4.27 \mathrm{a}$ & $4.29 \mathrm{a}$ & 0.534 \\
\hline \multirow[t]{2}{*}{8} & Epi- $\alpha$-cadinol & 33.679 & 1644 & 1640 & $5.60 \mathrm{a}$ & $3.33 \mathrm{a}$ & $6.22 \mathrm{a}$ & $5.26 \mathrm{a}$ & 0.451 \\
\hline & Total identified (\%) & & & & 93.71 & 96.07 & 93.60 & 94.28 & \\
\hline
\end{tabular}

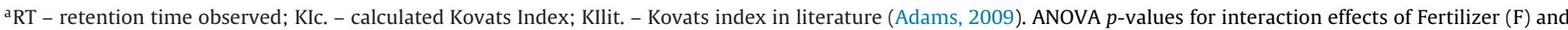

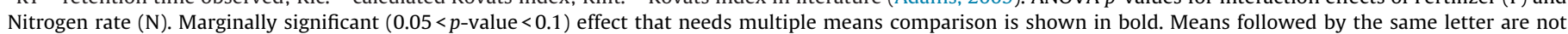
significantly different. 
abundance of major compounds in essential oil or to the European basil classified because has linalool with main component (Marotti et al., 1996).

Previous studies reported linalool and methyl chavicol as the major compounds found in basil essential oil. This variation may be associated with the origin of the plant, for example, in Australia and India, there was predominance of methyl chavicol and in France, Seychelles, and the United States was linalool (Lachowicz et al., 1996; Zheljazkov et al., 2008a,b) as we found in our study (Table 3). Moreover, in our study we also did not find the presence of methyl chavicol in sweet basil essential oil (Fig. 1).

\section{Conclusions}

Plants grown under conventional fertilizer responded positively to higher levels of $\mathrm{N}$, showing both higher fresh and dry weights than organically grown plants. On the other hand, basil plants at $150 \mathrm{~kg} \mathrm{~N} /$ ha application rate with organic fertilizer showed better growth parameters, revealing a higher concentration of tissue nutrients and higher fresh and dry weight. Regarding the essential oil composition, the $\mathrm{N}$ treatments did not change the oil profile of the basil plants under organic and conventional fertilization. Our results suggest that plants grown with conventional and organic fertilizer showed similar essential oil composition. The chemical profile of basil oil in this study was similar to basil oil in previous reports. This study shows that organic or conventional fertilizer can alter fresh or dry weight and nutrient absorption without modifying essential oil composition. Thus, organic fertilizer can be used without compromising the essential oil profile, preserving the bioactive compounds and properties that basil has in its essential oil composition.

\section{Acknowledgments}

Authors thank Ms. Amber Reichley and Mr. Solomon Green III, Natural Products Utilization Research Unit, USDA-ARS, for technical assistance. Thanks go to CAPES (Process 4873-13) and CNPq, for a Doctor's Degree scholarship granted to the first author.

\section{References}

Adams, R.P., 2009. Identification of Essential Oil Components by Gas Chromatography Mass Spectrometry, 4th ed. Allured Books, IL, USA, pp. pp. 804.

Anwar, M., Patra, D.D., Chand, S., Kumar, A., Naqvi, A.A., Khanuja, S.P.S., 2005. Effect of organic manure sand inorganic fertilizer on growth, herb and oil yield nutrient accumulation, and oil quality of French basil. Commun. Soil Sci. Plant Anal. 36, 1737-1746.

Arabaci, O., Bayram, E., 2004. The effect of nitrogen fertilization and different plant densities on some agronomic and technologic characteristic of Ocimum basilicum L. (basil). J. Agron. 3, 255-262.

Barbieri, G., Vallone, S., Orsini, F., Paradiso, R., De Pascale, S., Negre-Zakharov, F. Maggio, A., 2012. Stomatal density and metabolic determinants mediate salt stress adaptation and water use efficiency in basil (Ocimum basilicum L.). J. Plant Physiol. 169, 1737-1746.

Berry, P.M., Sylvester-Bradley, R., Philipps, L., Hatch, D.J., Cuttle, S.P., Rayns, F.W Gosling, P., 2002. Is the productivity of organic farms restricted by the supply of available nitrogen? Soil Use Manage. 18, 248-255.

Biasi, L.A., Machado, E.M., Kowalski, A.P.J., Signor, D., Alves, M.A., Lima, F.I. Deschamps, C., Côcco, L.C., Scheer, A.P., 2009. Organic fertilization in the production: yield and chemical composition of basil chemotype eugenol. Hortic. Bras. 27, 35-39.

Bowes, K., Zheljazkov, V.D., 2004. Ocimum sanctum L. and Ocimum basilicum L. grown in Nova Scotia: Canada show potential as essential oil crops. J. Am. Soc. Hortic. Sci. 129, 789-794.

Carrubba, A., 2009. Nitrogen fertilization in coriander (Coriandrum sativum L.) a review and meta-analysis. J. Sci. Food Agric. 89, 921-926.

Ekren, S., Sönmez Ç, Özcakal, E., Kurttas, Y.S.K., Bayram, E., Gürgülü, H., 2012. The effect of different irrigaton water levels on yield and quality characteristics of purple basil (Ocimum basilicum L.). Agric. Water Manage. 109, 155-161.

Golez, A., Politycka, B., Seidler-Lozykowska, B., 2006. The effect of nitrogen fertilization and stage of plant development on the mass and quality of sweet basil leaves (Ocimum basilicum L.). Herba Polonica 52, 22-30.
Grayer, R.G., Kite, G.C., Goldstone, F.J., Bryan, S.E., Paton, A., Putievsky, E., 1996. Infraspecific taxonomy and essential oil chemotypes in basil Ocimum basilicum. Phytochem. 43, 1033-1039.

Grayer, R.J., Vieira, R.F., Price, A.M., Kite, G.C., Simon, J.E., Paton, A.J., 2004 Characterization of cultivars within species of Ocimum by exudates flavonoid profiles. Biochem. Syst. Ecol. 32 (10), 901-913.

Hossain, F., Follett, P., Vu, K.D., Salmieri, S., Senoussi, C., Lacroix, M., 2014a. Radiosensitization of Aspergillus niger and Penicillium chrysogenum using basil essential oil and ionizing radiation for food. Food Control 45, 156-162.

Hossain, F., Lacroix, M., Salmieri, S., Vu, K., Follett, P.A., 2014b. Basil oil fumigation increases radiation sensitivity in adult Sitophilus oryzae (Coleoptera: Curculionidae). J. Stored Prod. Res. 59, 108-112.

Hussain, A.I., Anwar, F., Sherazi, S.T.H., Przybylski, R., 2008. Chemical composition, antioxidant and antimicrobial activities of basil (Ocimum basilicum) essential oils depends on seasonal variations. Food Chem. 108, 986-995.

Isaac, R., Johnson, W.E., 1975. Collaborative study of wet and dry ashing techniques for the elemental analysis of plant tissue by atomic absorption pectrophotometry. J. AOAC 58, 3.

Jones, J.B., Steyn, W.J.A., 1973. Sampling, handling and analyzing plant tissue samples. In: Walsh, L.M., Beaton, J.D. (Eds.), Soil Testing and Plant Analysis. Soil Sci. Soc. Amer, Madison, WI, pp. 249-270.

Karagözlü, N., Ergönül, B., Özcan, D., 2011. Determination of antimicrobial effect of mint and basil essential oils on survival of E. coli 0157:H7 and S. typhimurium in fresh-cut lettuce and purslane. Food Control 22, 1851-1855.

Keita, S.M., Vincent, C., Schmit, J.P., Arnason, J.T., Belanger, A., 2001. Efficacy of essential oil of Ocimum basilicum L. and O. gratissimum L. applied as an insecticidal fumigant and powder to control Callosobrochus maculatus (Fab) (Coleoptera Bruchidae). J. Stored Prod. Res. 37, 339-349.

Khalid, K.A., 2006. Influence of water stress on growth, essential oil and chemical composition of herbs (Ocimum sp.). Int Agrophys. 20 (4), 289-296.

Lachowicz, K.J., Jones, G.P., Briggs, D.R., Bienvenu, F.E., Palmer, M.V., Ting, S.S.T. Hunter, M., 1996. Characteristics of essential oil from basil (Ocimum basilicum L:) grown in Australia. J. Agric. Food Chem. 44, 877-881.

Lawrence, B.M., 1988. A further examination of the variation of Ocimum basilicum L. In: Lawrence, B.M., Mookerjee, B.D., Willis, B.J. (Eds.), Flavors and fragrances: A world perspective. Elsevier Sci. Publ. B.V, Amsterdam, pp. 161-170.

Lee, J., Scagel, C.F., 2009. Chicoric acid found in Basil (Ocimun basilicum L.) leaves. Food Chem. 115, 650-656.

Lee, S.J., Umano, K., Shibamoto, T., Lee, K.G., 2005. Identification of volatile components in basil (Ocimum basilicum L.) and thyme leaves (Thymus vulgaris L.) and their antioxidant properties. Food Chem. 91, 131-137.

Lu, Y., Gao, B., Chen, P., Charles, D., Yu, L.L., 2014. Characterisation of organic and conventional sweet basil leaves using chromatographic and flow-injection mass spectrometric (FIMS) fingerprints combined with principal component analysis. Food Chem. 154, 262-268.

Lucchesi, M.E., Chemat, F., Smadja, J., 2004. Solvent-free microwave extraction of essential oil from aromatic herbs: Comparison with conventional hydro-distillation. J. Chromatogr. A 1043 (2), 323-327.

Marotti, M., Piccaglia, R., Giovanelli, E., 1996. Differences in essential oil composition of basil (Ocimum basilicum L.): Italian cultivars related to morphological characteristics. J. Agric. Food Chem. 44, 3926-3929.

Montgomery, D.C., 2013. Design and Analysis of Experiments, 8th ed. New York, Wiley.

Morris, J.A., Khettry, A., Seitz, E.W.M., 1979. Antimicrobial activity of aroma chemicals and essential oils. J. Am. Oil Chem. Soc. 56, 595-603.

Nelson, D.W., Soommers, L.E., 1972. A simple digestion procedure for estimation of total nitrogen in soils and sediments. J. Environ. Qual. 19, 1-14.

Ozcan, M., Arslan, D., Unver, A., 2005. Effect of drying methods on the mineral content of basil (Ocimum basilicum L.). J. Food Eng. 69 (3), 375-379.

Pascual-Villalobos, M.J., Ballesta-Acosta, M.C., 2003. Chemical variation in an Ocimum basilicum germoplasm collection and activity of the essential oils on Callosobruchus maculatus. Biochem. Syst. Ecol. 31, 673-679.

Pirbalouti, A.G., Mahdad, E., Craker, L., 2013. Effects of drying methods on qualitative and quantitative properties of essential oil of two basil landraces. Food Chem. 141, 2440-2449.

Popovic, Z., Kostic, M., Popovic, S., Skoric, S., 2006. Bioactivities of essential oils from basil and sage to Sitophilus oryzae L. Biotechnol. Biotechnol. Equip. 20, 36-40.

Potter, T.L., 1996. Essential oil composition of cilantro. Agric. Food Chem. 44, 1824-1826.

Rasouli-Sadaghian, M., Hassani, A., Barin, M., Danesh, Y.R., Sefidkon, F., 2010. Effects of arbuscular mycorrhizal (AM) fungi on growth, essential oil production and nutrients uptake in basil. J. Med. Plant Res. 4 (21), 2222-2228.

Sangwan, N.S., Farooqi, A.H.A., Shabih, F., Sangwan, R.S., 2001. Regulation of essential oil production in plants. Plant Growth Regul. 34, 3-21.

SAS Institute Inc, 2010. SAS OnlineDoc ${ }^{\circledR}$ 9.3. SAS Institute Inc., Cary, NC.

Seufert, V., Ramankutty, N., Foley, J.A., 2012. Comparing the yields of organic and conventional agriculture. Nature 485, 229-234.

Silva, F.G., Pinto, J.E.B.P., Cardoso, M.G., Sales, J.F., Mol, D.J.S., Divino, S.P., 2006. Influence of manure and fertilizer on Baccharis trimera (Less.) D. C. growth and essential oil yield. J. Herbs Spices Med. Plants 12, 1-11.

Simon, J.E., Morales, M.R., Phippen, W.B., Vieira, R.F., Hao, Z., 1999. Basil: a source of aroma compounds and popular culinary and ornamental herb. In: Janick, J., Simon, J.E. (Eds.), Perspectives on New Crops and New Uses. ASHS, Alexandria, VA, pp. 499-505. 
Sinfola, M.I., Barbieri, G., 2006. Growth: yield and essential oil content of three cultivars of basil grown under different levels of nitrogen in the Field. Sci. Hortic. 108, 408-413.

Singh, K., Chand, S., Yaseen, M., 2014. Integrated nutrient management in Indian basil (Ocimun basilicum). Ind. Crop Prod. 55, 225-229.

Surveswaran, S., Cai, Y.-Z., Corke, H., Sun, M., 2007. Systematic evaluation of natural phenolic antioxidants from 133 Indian medicinal plants. Food Chem. 102, 938-953.

Teles, S., Pereira, J.A., Oliveira L.M. de Malheiro, R., Machado, S.S., Lucchese, A.M., Silva, F., 2014. Organic and mineral fertilization influence on biomass and essential oil production: composition and antioxidant activity of Lippia origanoides H.B.K. Ind. Crop Prod. 59, 169-176.

Topalov, V.D., 1962. E Ssential Oil and Medicinal Plants. Hr. G. Danov Press, Plovdiv, Bulgaria.
Umerie, S.C., Anaso, H.U., Anyasoro, J.C., 1998. Insecticidal potentials of Ocimum basilicum leaf-extract. Biores. Technol. 64, 237-239.

Yang, Y., Kayan, B., Bozer, N., Pate, B., Baker, C., Gizir, A.M., 2007. Terpene degradation and extraction from basil and oregano leaves using subcritical water. J. Chromatogr. A 1152, 262-267.

Zheljazkov, V.D., Callahan, A., Cantrell, C.L., 2008a. Yield and oil composition of thirty-eight basil (Ocimum basilicum L.) accessions grown in Mississippi. J. Agric. Food Chem. 56, 241-245.

Zheljazkov, V.D., Cantrell, C.L., Ebelhar, M.W., Rowe, D.E., Coker, C., 2008 b. Productivity, oil content, and oil composition of sweet basil as a function of nitrogen and sulfur fertilization. Hortic. Sci. 43, 1415-1422. 